\title{
Work Discipline Factors Affecting Employees Performance Of Marketing Subdivision of Madika Foundation In Surabaya
}

\author{
Fajar Tinovitasari ${ }^{1}$, Rika Yuliastanti ${ }^{2}$, Fianita Malati ${ }^{3}$ \\ ${ }^{123}$ Mahardhika Economics School \\ rikayuliastanti@gmail.com
}

\begin{abstract}
Purpose : To generate good employee performance, then employee discipline factors need to be improved and maintained continuity.

Design/methodology/approach : Research approach, Quantitative approach is research that focuses on testing the hypothesis. Data used should be measurable and will result in generalizable conclusions. This research was causal because it would examine the influence between variables.

Findings The result of CAAR is showed that CAAR abnormal return significantly merely happen in research period III. While, for t-test towards AAR showed that abnormal return happened in period II and III tax amnesty execution

Research limitations/implications : The object of this research is company which recorded as a member in LQ45 indexes.

Practical implications : The result of CAAR is showed that CAAR abnormal return significantly merely happen in research period III. While, for t-test towards AAR showed that abnormal return happened in period II and III tax amnesty execution, with details in period II abnormal return merely happen in $\mathrm{t}-1$ with negative value and period III abnormal return happen in $t-9, t-8, t-4, t-3, t+1$ and $\mathrm{t}+9$.

Originality/value : In improving work discipline, assertiveness imposed on employees who violate discipline should also be noted.

Paper type : Research paper
\end{abstract}

Keyword : Discipline, Achievement/Performance, Leader

Work Discipline Factors Affecting Employees Performance Of Marketing Subdivision of Madika Foundation In Surabaya

Fajar Tinovitasari, Rika Yuliastanti, Fianita Malati 


\section{INTRODUCTION}

To obtain reliable human resources, the Foundation must be able to create conditions that can encourage and enable employees to develop and improve capabilities it has optimally. In managing employees there are various things that affect, there are: work discipline, where this work discipline will play a role in determining the efficiency and effectiveness of the work of employees in completing their work. In fact, even not rarely the problem of employee work discipline causes special problems in the process of achieving the Foundation's objectives, so that required in-depth study.

According to Hasibuan (2002:194-198) basically many factors that affect employee discipline level of an organization, such as: exemplary leadership, supervision attached (waskat), and punishment sanctions. Therefore a Foundation needs to have various provisions that must be obeyed by its employees. Discipline is a management action to encourage employees to fulfill the demands of various standards that employees must be fulfilled.

While the disciplinary action according to Gomes (2000: 231) could be "reprimands, suspensions, reductions in rank or pay, and firings. These disciplinary actions are caused by specific employee behavior events that lead to low performance or violations of agency rules ".

Similarly, what happened to Madika Foundation in Surabaya, the Foundation realized the importance of employees discipline, especially employees of marketing. Marketing employees are the spearhead of the Foundation in generating company's revenue. The existence of undisciplined will result in unfulfilled marketing targets that have been set. As a result the Foundation has low sales and small revenues as well. Therefore, employees work discipline should always be considered with the hope of employees performance of marketing subdivision can be maintained properly.

Based on the description of the background, it is interesting to do a study

Work Discipline Factors Affecting Employees Performance Of Marketing Subdivision of Madika Foundation In Surabaya

Fajar Tinovitasari, Rika Yuliastanti, Fianita Malati 
with the title "Work Discipline Factors Affecting Employees Performance of Marketing Subdivision of Madika Foundation in Surabaya".

\section{Problem of the Study}

Based on the above description, then the problems encountered can be formulated as follows:

1. How employee discipline factors covering exemplary leadership, supervision attached (waskat), punishment sanctions, and punishment sanctions collectively have significant influence on employee performance of marketing subdivision of Madika Foundation in Surabaya?

2. Which factors of employee discipline variable covering exemplary leadership, supervision attached (waskat), punishment sanctions, and punishment sanctions which have dominant influence to employee performance of marketing subdivision of Madika Foundation in Surabaya?

\section{MATERIAL AND METHOD}

Research approach, Quantitative approach is research that focuses on testing the hypothesis. Data used should be measurable and will result in generalizable conclusions. This research was causal because it would examine the influence between variables. This approach started with hypotheses and theories, the next step was to create the model analysis, identifying variables, making operational definitions, collecting data (either primary or secondary) based on population and sample as well as perform analysis.

Work Discipline Factors Affecting Employees Performance Of Marketing Subdivision of Madika Foundation In Surabaya

Fajar Tinovitasari, Rika Yuliastanti, Fianita Malati 


\section{Identify Variables}

The variables to be studied in this thesis can be identified as follows:

1. Dependent variable, is variable which the value depends on the value of another variable (independent variable). This variable is given the symbol $\mathrm{Y}$, i.e. performance of marketing subdivision of Madika Foundation in Surabaya.

2. Independent variable, is variable which the value affects the value of another variable. This variable is given the symbol X, i.e. work discipline factors consisting of: a) $\mathrm{X}_{1}$ : Exemplary Leadership; b) $\mathrm{X}_{2}$ : Supervision Attached (Waskat); c) $\mathrm{X}_{3}$ : Assertiveness e); $\mathrm{X}_{4}$ : Punishment Sanctions.

Types and data sources used primary data and secondary data

\section{Data collection procedures}

The population of this research is employees, employee performance (work achievement), considering the number of population is not so great, i.e. 35 , hence all member of population selected as sample. This 35 total samples can be said to be decent because according to Roscoe (Sugiyono, 2001:12) the decent sample standard used for research between 30-500. Determination technique of sample used is census technique where every employee will be respondent.

A measuring instrument can be said to be valid if it gives corresponding measuring result with the purpose of the measurement. Test Validity in this research by using the criteria taken from the measuring instrument itself, i.e. by correlating between the items score with the total score (whole items), called the validity of items using internal criteria. And a measurement tool is said to be reliable if it gets the same fixed results from unchanged measurement phenomena/symptoms performed at different times. Reliability is an index that indicates the extent to which measurement tools are trustworthy or reliable.

Work Discipline Factors Affecting Employees Performance Of Marketing Subdivision of Madika Foundation In Surabaya

Fajar Tinovitasari, Rika Yuliastanti, Fianita Malati 
Instruments are said to be reliable when used multiple times to measure the same object will produce the same data. The technique used to test reliability is to use alpha scale (Alpha Cronbach). Technique of analysis and data processing will be done to test the hypothesis of statistical research with multiple linear regression analysis as the tool of test.

1. Simultaneous test done with F-test to find out whether all free variables simultaneously have significant influence on the bound variables. And partial test (t-test) and interpretation of partial $r 2$ to discover the partially significant influence of free variable to the bound variable. And be evaluated with the intention to whether the use of multiple regression linear model (Multi Regression Linear) in analyzing has fulfilled classical assumption. Multiple linear regression models will be more appropriate to use and produce more accurate calculations, if some of the following assumptions can be fulfilled: multicollinearity, heteroscedidity.

\section{RESULT AND DISCUSSION}

Characteristics of respondents according to age level showed where respondents aged 18-22 years as many as 1 person or $3 \%$, respondents aged 23-27 years as many as 12 people or 34\%, respondents aged 28-32 years as many as 11 people or 31\%, respondents aged 33-37 years as many as 6 people or $17 \%$, respondents aged $38-42$ years as many as 3 people or $9 \%$, and respondents older than 42 years.

Characteristics of respondents according to recent education showed the last level of education, where respondents with senior secondary education (senior high school) level or equivalent as many as 3 people or $9 \%$, respondents with final education Diploma or equivalent as many as 11 people or $31 \%$ and respondents with undergraduate education as many as 21 people

Work Discipline Factors Affecting Employees Performance Of Marketing Subdivision of Madika Foundation In Surabaya

Fajar Tinovitasari, Rika Yuliastanti, Fianita Malati 
Volume 1 Number 12017

This work is licensed under a Creative Commons Attribution-

ShareAlike 4.0 International License.

or $60 \%$.

Characteristics of respondents according to working period (tenure) showed respondents with tenure less than 5 years as many as 5 people or $14 \%$, respondents with tenure 5-10 years as many as 17 people or $49 \%$, respondents with tenure of $10-15$ years as many as 11 people or $31 \%$, and respondents with tenure more than 15 years as many as 2 people or $6 \%$.

\section{Variable Description}

The results showed that all discipline factors consisting of exemplary leadership, supervision attached (waskat), assertiveness and punishment sanctions according to respondents' assessment were good. This showed that discipline factors in the company had been run well, and foster good discipline for employees. Companies need to maintain this condition, and even if it could improve these factors even better. Because the decline in these discipline factors would be bad affect for employee performance.

Description of Performance Variable $(Y)$ with the category of assessment as on discipline factors, for performance variables, the results showed that the overall average value for performance variables was 3.88 , which indicated that employee performance was good.

\section{Validity Testing and Reliability}

Test results on the Validity of statement items for all variables, all of which were valid because the value of $r$ count of each statement item was greater than the critical $r$ value of 0.300 . While Reliability all variables had alpha above the value of 0.6 , so it could be concluded that the statement device used to measure each variable could be relied upon. 


\section{Model Analysis and Hypothesis Testing}

The analytical technique used in this research was Multiple Linear Regression, with employee performance as a bound variable $(Y)$, and free variables of exemplary leadership $\left(X_{1}\right)$, waskat $\left(X_{2}\right)$, assertiveness $\left(X_{3}\right)$, and punishment sanctions $\left(\mathrm{X}_{4}\right)$. Based on the results of regression analysis obtained results such as:

$$
Y=0,88+0,192 X_{1}+0,270 X_{2}+0,153 X_{3}+0,156 X_{4}
$$

The results of regression analysis also showed that the contribution of free variables, exemplary leadership $\left(X_{1}\right)$, waskat $\left(X_{2}\right)$, assertiveness $\left(X_{3}\right)$, and punishment sanctions $\left(\mathrm{X}_{4}\right)$, to a bound variable, performance $(\mathrm{Y})$, which was indicated by the magnitude of the determination coefficient $\left(R^{2}\right)$ was 0.696 . This means that $69.6 \%$ of the rate of change in employee performance was determined by the change of all free variables included in the regression model. Thus $30.4 \%$ employee performance level was still determined by other variables.

The value of multiple correlation coefficient or multiple regresion $(R)$ based on the result of analysis was 0.834 . This coefficient indicated the correlation level of a bound variable $(\mathrm{Y})$ performance (work achievement) to free variables, exemplary leadership $\left(X_{1}\right)$, waskat $\left(X_{2}\right)$, assertiveness $\left(X_{3}\right)$, and punishment sanctions $\left(X_{4}\right)$. The high value of $R$, which was 0.834 , indicated a strong relationship between all free variables, i.e. exemplary leadership $\left(X_{1}\right)$, waskat $\left(X_{2}\right)$, assertiveness $\left(X_{3}\right)$, and punishment sanctions $\left(X_{4}\right)$ with a bound variable, performance (work achievement) ( $\mathrm{Y}$ ).

In the use of the regression model, there are some basic assumptions that can yield the best unbiased linear estimate of the regression model derived from the Ordinary Least Square method.

Multicollinearity means between one free variable and the other independent variables in the regression model are correlated. Usually, the

Work Discipline Factors Affecting Employees Performance Of Marketing Subdivision of Madika Foundation In Surabaya

Fajar Tinovitasari, Rika Yuliastanti, Fianita Malati 
correlation is near perfect or perfect (the correlation coefficient is high or close to one). From the calculation of VIF value the overall of free variable is less than the critical value of VIF of 10 , so it can be concluded that the model does not occur multicollinearity symptoms.

Heteroscedasticity means that variation (variance) variables are not the same for all observations. And to see occurred or not of heteroscedasticity, then seen from Rank Spearman correlation coefficient value between each independent variable with bully variable, and from the results of the error calculation (Sig) is greater than the significant level $(\alpha) 0.05$, then there is no heteroscedasticity.

\section{Hypothesis Testing}

The first hypothesis stated that employee discipline factors, which included exemplary leadership, supervision attached (waskat), punishment sanctions, and punishment sanctions collectively had significant influence on employee performance of marketing subdivision of Madika Foundation in Surabaya. Based on the result of regression analysis seen that the value of $F$ count was 17,138 , with error probability value (Sig) equal to 0.000 . The value of $F$ table for the significant level $\alpha=0.05$ with df (4.30) was equal to 2.69. Because the value of $\mathrm{F}$ count of $17.138>\mathrm{F}$ table value of 2.69 and error probability value (Sig) of 0,000 was smaller than significance level of $5 \%$ significance level, then independent variables, i.e. exemplary leadership $\left(X_{1}\right)$, supervision attached (waskat) $\left(\mathrm{X}_{2}\right)$, assertiveness $\left(\mathrm{X}_{3}\right)$, and punishment sanctions $\left(\mathrm{X}_{4}\right)$, simultaneously had significant influence on the dependent variable $(Y)$ work achievement (performance). This means that the first hypothesis stating that employee discipline factors, which included exemplary leadership, supervision attached (waskat), punishment sanctions, and punishment sanctions collectively

Work Discipline Factors Affecting Employees Performance Of Marketing Subdivision of Madika Foundation In Surabaya

Fajar Tinovitasari, Rika Yuliastanti, Fianita Malati 
Volume 1 Number 12017

This work is licensed under a Creative Commons Attribution-

ShareAlike 4.0 International License.

had significant influence on employee performance of marketing subdivision of Madika Foundation in Surabaya, proved true.

And that employee work discipline factors, which included exemplary leadership, supervision attached (waskat), punishment sanctions, and punishment sanctions partially had significant influence on employee performance of marketing subdivision of Madika Foundation in Surabaya, obtained analysis results of t-test with significant level of $5 \%$ and $\mathrm{df}=30$, explained things as follows:

1. Exemplary leadership variable $\left(X_{1}\right)$ had significant influence on performance variables $(Y)$, with error probability level of 0.023 which was smaller than significance level of 0.05 .

2. Supervision attached (Waskat) variable $\left(X_{2}\right)$ had significant influence on performance variable $(Y)$, with error probability level of 0.040 which was smaller than significance level of 0.05 .

3. Assertiveness variable $\left(X_{3}\right)$ had significant influence on performance variable $(Y)$, with error probability level of 0.008 which was smaller than significance level of 0.05 .

4. Punishment sanctions variable $\left(X_{4}\right)$ had significant influence on performance variable $(Y)$, with error probability level of 0.029 which was smaller than significance level of 0.05 .

Based on the analysis results of t-test could be concluded that all independent variables had significant influence on dependent variable. This means that the second hypothesis stated that employee discipline factors, which included exemplary leadership, supervision attached (waskat), punishment sanctions, and punishment sanctions partially had significant influence on employee performance of marketing subdivision of Madika Foundation in Surabaya, proved true.

Work Discipline Factors Affecting Employees Performance Of Marketing Subdivision of Madika Foundation In Surabaya

Fajar Tinovitasari, Rika Yuliastanti, Fianita Malati 
The second hypothesis stated that assertiveness factor had a dominant influence on employee performance of marketing subdivision of Madika Foundation in Surabaya. To prove this, could be seen from the value of the highest partial correlation coefficient among all discipline factors, because the value of the highest partial correlation coefficient was the dominant indication of the influence of one of variables.

Thus, the results of research analysis showed that the overall factors of employee discipline, which included exemplary leadership, supervision attached (waskat), assertiveness, and punishment sanctions had significant influence on employee performance. This showed the importance of work discipline factors in supporting employee performance, the more discipline employees perform their duties, the better their work achievement (performance).

\section{DISCUSSION}

Human beings are the main and most important factor in the organization which of course can not be treated the same as other factors of production within the company. According to Handoko (2000:4) the definition of human resource management is "withdrawal, selection, development, maintenance, and use of human resources to achieve the objectives either individual or organization". Here Handoko emphasizes human management, not other resources. The success of organizational management is determined by human resource utilization activities.

So that human resource management is the most important and vital part for the achievement of organizational or company goals, it is also the utilization of various functions and personnel activities to ensure that the labor is used effectively and wisely.

According to Ntisemito (2000:199), work discipline is "an attitude, behavior and act in accordance with the rules of the organization, either written and

Work Discipline Factors Affecting Employees Performance Of Marketing Subdivision of Madika Foundation In Surabaya

Fajar Tinovitasari, Rika Yuliastanti, Fianita Malati 
unwritten rules". Work discipline is very important for the development of the company and the employee survival in the future. Many things in the company's performance are influenced by employee work discipline, some of which involve the level of productivity and efficiency levels.

Simamora (1999:565) defined work discipline as "a form of employee selfcontrol and regular implementation and shows the level of seriousness of team work within an organization." It further explained that disciplinary action demands a punishment against an employee who fails to fulfill prescribed standards. Disciplinary actions are implemented incorrectly are destructive for employees and organization. Thus, discipline for employees should be done in earnest and disciplinary action should not be applied in haphazardly.

According to Davis, quoted by Mangkunegara (2000: 129) explained that "Dicipline is management action to enforce organization standards". Based on Davis's opinion it appears that work discipline can be interpreted as the implementation of management to strengthen the organization's guidelines.

Handoko (2001:208) gave the sense of discipline as "management activities to implement organizational standards". According to Davis and Newstrom (1996:88), the purposes of disciplinary action are as follows: a) Improving the behavior of standard offenders, b) Preventing others from doing similar actions, c) Maintaining consistent group standards and effective. The purposes of disciplinary action are to positively educate and improve. The goal is to improve behavior in the future and not to punish past behavior.

According to Davis and. Werther (1996:423-425) there are two types of employee discipline are: 1) Preventive discipline, 2) Corrective discipline. To be able to run the discipline of employees well, it is necessary the existence of actions or disciplinary steps ranging from the lightest to the hardest. As Siagian said (1998:306-307), the stages of the disciplinary steps are: a. Verbal warning by supervisor, b. A written statement of dissatisfaction by direct superior, c.

Work Discipline Factors Affecting Employees Performance Of Marketing Subdivision of Madika Foundation In Surabaya

Fajar Tinovitasari, Rika Yuliastanti, Fianita Malati 
Postponement of periodic salary increases, d. Postponement promotion, e. Exemption from office, f. Temporary termination, $g$. Termination upon own request, h. Termination/dismissal with disrespect upon own request, and Termination/dismissal with disrespect.

While Davis and Newstrom (1996: 90) proposed the implementation of progressive disciplinary policy, which means that the repetition of the violation is imposed more severe punishment. Mangkunegara (2000:131) said that "the implementation of sanctions against disciplinary violation by giving warning, should be immediate, consistent, and impersonal". Davis and Newstrom (1996:91) described the disciplinary system with the image below. "The first violation committed causing the oral reprimand from the supervisor.

Nawawi (1997:234) mentioned work achievement (performance) with the term opus, i.e. "the results of the implementation of a job, either physical/material or non-physical/non-material". Mangkunegara (2000:67) defined performance as "the result of work in quality and quantity achieved by an employee in performing his duties in accordance with the responsibilities given to him".

Cascio (1995:275) stated that "Performance refers to an employee's accomplishment of assigned tasks" viewed performance as how much attainment or fulfillment of duties imposed on employees.

According to Gomes (2000:142), "quantitative performance measures such as units of production and sales volume generate relatively consistent measurements". Subjective criteria, such as attitude, creativity, and cooperation, resulting in less consistent measurements, depending on who is evaluating, and how the measurements were done. Furthermore Gomes (2000: 142) suggested several types of work performance criteria based on specific behavior descriptions, that are: 1) Quantity of work; i.e. the amount of work obtained within a specified period of time; 2) Quality of work; i.e. the quality of

Work Discipline Factors Affecting Employees Performance Of Marketing Subdivision of Madika Foundation In Surabaya

Fajar Tinovitasari, Rika Yuliastanti, Fianita Malati 
work achieved under the conditions of conformity and readiness; 3) Job knowedge, i.e. the breadth of knowledge about work and skills; 4) Creativeness; i.e. the originality of the ideas presented and actions to resolve the problems that arise; 5) Cooperative; i.e. the willingness to cooperate with others (fellow members of the organization); 6) Dependability; i.e. awareness and credibility in the terms of attendance and work completion; 7) Initiative; i.e. the spirit to carry out new tasks and in enlarging their responsibilities; 8) Personal qualities; i.e. concerning personality, punishment sanction, hospitality, and personal integrity.

In the management function, when a mission has been applied in various levels of planning, then the next action is to implement it in accordance with the direction of the objectives will be achieved. The implementation process requires supervision that is done through Performance appraisal.

Cascio (1995:275), defined Performance appraisal as "... the sytematic discription of the job relevance strengths and weaknesses of an individual or a group". Another definition put forward by Werther and Davis (1996:341), "Performance appraisal is the process by which organization evaluation individual job performance." This definition explains the process of performance appraisal with a simple meaning. Performance appraisal is defined as the process by which the organization evaluates employee performance.

According Soeprihanto (2000:37-49) divided the methods of performance appraisal in two major groups, i.e. "past oriented appraisal method and future oriented appraisal method". Past oriented approaches have an advantage in assessing performance in comparison with to future oriented, in which employees can get feedback that can provide an incentive to improve their performance. The disadvantage is that performance that has been realized in the past can not be changed anymore.

Past-oriented methods include: 1) Rating scale, 2) Checklist, 3) Critical

Work Discipline Factors Affecting Employees Performance Of Marketing Subdivision of Madika Foundation In Surabaya

Fajar Tinovitasari, Rika Yuliastanti, Fianita Malati 
incident method, 4) Method of re-examination of field information (field review method), 5) Performance and observation tests (performance tests and observations). 6) Group evaluation method.

Nawawi (1997:248-251) says that "performance appraisal has broad dimension of purposes, that are general purpose and special purpose", Simamora (1999:423) said that the ultimate purpose of employee performance appraisal is to produce accurate information about behavior and the performance of the organization's members. These objectives can be classified into two major categories: evaluation and development. These two goals are not separated but indirectly different in terms of time orientation, the methods and roles of superiors and subordinates. By combining evaluation and development aspects, performance appraisal should provide the basis for personnel decisions and improve the utilization of human resources through better job placement.

Hasibuan (2002:193) explained that "discipline is the most important operative function on MSDM because the better employee discipline, the higher performance that can be achieved. Without good employee discipline, it is difficult for a company's organization to achieve optimal results".

Based on background of the problem, problem of the study, and supported by several existing theories, then the research hypothesis stated as follows:

1. Employee discipline factors covering exemplary leadership, supervision attached (waskat), punishment sanction, and punishment sanctions collectively have significant influence on employee performance of marketing subdivision of Madika Foundation in Surabaya.

2. The assertiveness factor has dominant influence on employee performance of marketing subdivision of Madika Foundation in Surabaya.. 


\section{CONCLUSION}

Based on the results of research analysis, it could be concluded as follows:

1. Employee discipline factors covering exemplary leadership, supervision attached (waskat), punishment sanctions, and punishment sanctions collectively had significant influence on employee performance of marketing subdivision of Madika Foundation in Surabaya.

2. Assertiveness factors of Leadership had dominant influence on employee performance of marketing subdivision of Madika Foundation in Surabaya.

\section{REFERENCES}

Algifari. (2000). Analisis Regresi, Teori, Kasus dan Solusi. Edisi Kedua. Jogjakarta: BPE UGM.

Cascio, W.F. (1995). Managing Human Resources Productivity Quality of Work Life, Profits. $4^{\text {th }}$ Edition. Singapura: Mc Graw-Hill Book.

Davis, K. dan Newstrom, J.W. (1996). Perilaku Dalam Organisasi. Edisi Ketujuh. Jilid Dua. Jakarta: Penerbit Erlangga.

Dessler, G. (1997). Manajemen Sumber daya Manusia. Edisi bahasa Indonesia. Jakarta: Penerbit Prenhallindo.

Febrianti, D. (2002). Pengaruh Disiplin Kerja Terhadap Prestasi Kerja Karyawan Bagian Produksi PT. Pamolite Adhesive Industry Di Probolinggo. Skripsi. Unair

Gomes, F.C. (2000). Manajemen Sumebr Daya Manusia. Cetakan Kelima. Penerbit Jogjakarata: Andi Offset.

Handoko, T.H. (2001). Manajemen Personalia dan Sumber Daya Manusia. Yogjakarta: BPFE-UGM.

Hasibuan, M.S.P. (2002). Manajemen Sumber Daya Manusia. Edisi Revisi. Jakarta: Bumi Aksara.

Work Discipline Factors Affecting Employees Performance Of Marketing Subdivision of Madika Foundation In Surabaya

Fajar Tinovitasari, Rika Yuliastanti, Fianita Malati 
Malhotra, N.K., Hall, J., Shaw, M. and Crisp, M. (1996). Marketing Research: An Applied Orientation. Sydney: Prentice Hall.

Mangkunegara, A.A. dan Prabu, A. (2000). Manajemen Sumber Daya Manusia Perusahaan. Cetakan Kedua. Bandung: Remaja Rosdakarya.

Meiriane, T. (2004). Pengaruh Faktor-Faktor Kedisiplinan Kerja Terhadap Prestasi Kerja Pengemudi Bis Kota Damri di Surabaya. Skripsi. FE Unair.

Moenir, A.S. (1987). Manajemen Personalia (Manajemen Sumber Daya Manusia). Cetakan Keempat. Jakarta: Penerbit Ghalia Indonesia.

Nawawi, H. dan Martini, H. (1997). IImu Administrasi. Jakarta: Penerbit Ghalia Indonesia.

Nitisemito, A.S. (2000). Manajemen Personalia: Manajemen Sumber Daya Manusia. Edisi Ketiga. Jakarta: Ghalia Indonesia.

Robbins, S.P. (1996). Perilaku Organisasi. Edisi Bahasa Indonesia. Jakarta: PT. Prenhallindo.

Saydam, G. (2000). Manajemen Sumber Daya Manusia. Jilid Satu. Cetakan Kedua. Jakarta: Penerbit Gunung Agung.

Siagian, S.P. (1998). Manajemen Sumber Daya Manusia. Cetakan ketujuh. Jakarta: Bumi Aksara.

Simamora, H. (1999). Manajemen Sumber Daya Manusia. Cetakan Ketiga. Yogyakarta: YPPKN.

Singarimbun, M. dan Effendi, S. (1995). Metode Penelitian Survai. Cetakan Kedua. Jakarta: LP3ES.

Singodimedjo, M. dan Muhammad, N. (2000). Manajemen Sumber Daya Manusia. Surabaya: Surabaya Master Management and Administration Studies.

Siswanto, B. (1987). Manajemen Tenaga Kerja. Cetakan Kedua. Bandung: Penerbit Sinar Baru.

Work Discipline Factors Affecting Employees Performance Of Marketing Subdivision of Madika Foundation In Surabaya

Fajar Tinovitasari, Rika Yuliastanti, Fianita Malati 
Volume 1 Number 12017

This work is licensed under a Creative Commons Attribution-

ShareAlike 4.0 International License.

Soeprihanto, J. (2000). Penilaian Pelaksanaan Kerja dan Pengembangan

Karyawan. Cetakan Keempat. Yogyakarta: BPFE.

Sugiyono. (2001). Statistika Untuk Penelitian. Bandung: CV Alfabeta.

Suwardi, E. (1982). Aspek-Aspek Kepemimpinan dalam Manajemen Operasional. Bandung: Penerbit Alumni.

Work Discipline Factors Affecting Employees Performance Of Marketing Subdivision of Madika Foundation In Surabaya

Fajar Tinovitasari, Rika Yuliastanti, Fianita Malati 